\title{
INTERCULTURAL ASPECTS IN LANGUAGE EDUCATION
}

\author{
Titi Rokhayati \\ Universitas Muhammadiyah Purworejo, Indonesia
}

\begin{abstract}
Intercultural understanding essentiallybecomes a part of living with others in the diverse world of the twenty-first century. It assists people to become responsible local and global citizens through their education for living and working together in an interconnected world. Language is a major component and supporter of culture as well as a primary tool for transferring message, which is inextricably bound with culture. Language is a key component of culture. It is also a primary medium for transmitting the culture itself. Without language, culture would not be possible. Students learning their native language are learning their own culture. Meanwhile, learning a second language also involves learning a second culture to varying degrees. A language is influenced and shaped by culture. It reflects culture. Cultural differences are the most serious areas causing misunderstanding, unpleasantness and even conflict in cross-cultural communication. Both foreign language learners and teachers accordingly should pay more attention to cultural communication information.
\end{abstract}

Key words: language, communication, cross-culture.

\section{INTRODUCTION}

Learning a language is automatically learning the culture. When learning language all the expressions in language will be directly related to the culture. Each culture has its own peculiarities and throws special influence on the language system. We can obviously see that the meaning attributed to language is cultural-specific. A great deal of cross-cultural misunderstanding occurs when the "meanings" of words in two languages are assumed to be the same, but actually reflect different cultural patterns. Without understanding the culture one cannot understand and use the language well. The understanding of the content of the language much depends depends much on their understanding about the culture. It is assumed that one will not be able to express the language well if he neglects the culture. The target language which is studied will influence much on the aspects of the target language culture. There will be do's and dont's in learning the culture related to the appropriate behavior or language in expressing something.

This paper discussessome of the basic assumptions about language, culture and learning that characterise an interculturalaspect in language education.Intercultural understanding is an essential part of living with others in the diverse world of the twenty-first century. It assists people to become responsible local and global citizens, equipped through their education for living and working together in an interconnected world. 


\section{REVIEW OF RELATED LITERATURE}

\section{Language}

Language is a symbol system based on pure arbitrary conventions ... infinitely extendable and modifiable according to the changing needs and conditions of the speakers (Patel and Jain, 2008: 25). They also describe some characteristics of language, they are:

1. Language is culture-based

2. Language is unique system

3. Language is social behavior

4. Language is medium of instruction

5. Language is structural system

6. Language is made up habit.

From the definitions it can be inferred that thcharacteristic 1 and 6 are related to culture. The first characterizes that it is culture-based and itis made up habit. As we know that language is based on the culture means that thereis an expression of something because the 'things' are there or the things exist in thelanguage.

It is made up habit also refers to culture since culture is formed from habit and custom which are is shared in a society and by the time they it becomes culture. The relation between culture and language cannot be separated: if someone learns a language willy nilly he also learns the culture. As Brown says (2007: 189)that a language is a part of culture and a culture is a part of language.The two are intricately interwoven so that one cannot separate the two without losing the significance of either language or culture.

\section{Culture}

Culture as socialisation is understood as both a process and a product. Culture asmembership in a speech community, with shared assumptions about the world and one's place in it, is shared lifeworld, common history, subjective memories and language ideologies (Knapp and Seidlhofer, 2009: 227).

Culture as symbolic power focuses on the way culture becomes entangled with social control, social identity, and dominant discourses such as the fetishisation of communication in a communication culture(Knapp and Seidlhofer, 2009: 230).

Expressed most simply, culture means 'the way we see and do things'. Culture is the set of shared meanings or the ways people agree to be (behave, act, respond) in order to respond to new and familiar situations in their lives. Culture becomes the filter through which people interpret reality and perceive their future. As such, any particular culture represents a coherent but distinctive way of looking at the world (Brisbane Catholic Education, 1999).

No culture is wholly isolated, self-contained and unique. There are important resemblances that stem in part from diffusion and in part from the fact that all cultures are built around biological, psychological and social characteristics common to all mankind. Lyons refers to such common biological 
and cultural features as biological and cultural universals. That is why there is a greater or less degree of cultural overlap between any two societies and why people from different cultures have the possibility to communicate with each other. Cultural similarities and differences are central to the study of communication between members of different cultural groups because they affect all intercultural and cross-cultural communication. (http://www1.gdufs.edu.cn/jwc/bestcourse/kecheng/38/whiiaoan/ files/intro.html).

Matsumoto (2000:24) adds that culture is dynamic system of rules, explicit and implicit established by groups in order to ensure their survival, involving attitudes, values, beliefs, norms and behavior, shared by a group but harbored differently by each specific unit within the group, communicated across generation, relatively stable but with potential to change across time.

The key concept that are embedded in the definitions:

1. Dynamic

2. System of rules

3. Group and units

4. Survival

5. Attitude, values, beliefs, norm, behavior

6. Shared by a group

7. harbored differently by each specific unit

8. communicated across generation, relatively stable

9. potential to change across time

Seeing the concept of culture we can infer that culture consists of attitude, values, beliefs, norm, behavior which is dynamic, shared among a group of people to survive. Living in one culture means having the same concepts shared in the society and they try to survive in that society although it chenges over time.

\section{Intercultural Understanding}

Intercultural understanding focuses on creating and contesting different cultural perceptions and practices, and supports the development of a critical awareness of the processes of socialisation and representation that shape and maintain cultural differences.Intercultural understanding is the ability to participate and negotiate with people in a contexts. Participating and negotiating with people requires an ability to know and understand 'your' culture, 'another's' culture and have skill in working between your own and another's culture. (http://www.asiaeducation.edu.au/for_teachers/professional_learning/intercultural_compe tencies/developing intercultural understanding/diu resources/resource 1 definitions.ht $\underline{\mathrm{ml}}$.

Intercultural understandingassumes an integral connection between language and culture, acknowledging language as the primary means through which people establish and exchange shared meaning and ways of seeing the world (Scarino, Dellitt and Vale, 2007). It works on the assumption that, in learning to live together in a world of social, cultural, linguistic and religious 
diversity, students need to look beyond their immediate worlds and concerns (Arigatou Foundation, 2008) and engage with the experience and ideas of others (Appiah, 2006) in order to understand the politics of culture on the world stage (Sleeter and Grant, 2003).

Intercultural understanding identifies knowledge, skills, behaviours and dispositions that assist students in developing and acting with intercultural understanding at school and in their lives beyond school. At a personal level, Intercultural understanding encourages students to engage with their own and others' cultures, building both their sense of belonging and their capacity to move between their own worlds and the worlds of others (Kalantzis and Cope, 2005), recognising the attitudes and structures that shape their personal identities and narratives.

At a social level, Intercultural understanding builds students' sense of the complex nature of their own histories, traditions and values, and of the history, traditions and values Students learn to interpret and mediate cultural inequalities within their own and other societies. They learn to take responsibility for their interactions with others, to act on what they have learnt and to become intercultural citizens in the world (Byram, 2008).

Students develop intercultural understanding as they learn to value their own cultures, languages and beliefs, and those of others. They come to understand how personal, group and national identities are shaped, and the variable and changing nature of culture. The capability involves students in learning about and engaging with diverse cultures in ways that recognise commonalities and differences, create connections with others and cultivate mutual respect.

Students develop intercultural understanding through the study of the English language and the ways it has been influenced by different cultural groups, languages, speakers and writers. In interpreting and analysing authors' ideas and positions in a range of texts in English and in translation to English, they learn to question stated and unstated cultural beliefs and assumptions, and issues of intercultural meaning.

Students use intercultural understanding to comprehend and create a range of texts, that present diverse cultural perspectives and to empathise with a variety of people and characters in various cultural settings (http://www.australiancurriculum. edu.au/english/general-capabilities).

\section{DISCUSSION}

\section{Language and Culture in Education}

In FL education, culture is associatedwith the place where the conceptual metaphors, conversational style, socialisation pattern are on. So neglecting some aspects of culture will make the language learners 'blind' do not know how to live and behave, also interact with the speech communities.

The learners need to know about space, code-switchings in order to get meaning in the new culture. Learners are called upon to learn, understand and memorise cultural content. They are also challenged to analyse and interpret, 
make connections and discover patterns in a cultural context and relate their findings to their own subject position.

The way they make connections with the world can be in any topics. The way they speak is also influenced by their understanding about the use of target language.The way they see the concept of self will depend on the target language use, i.e. the concept of individualist they observe that the language they learn is more individualist than theirs.It can be seen in the reflection of reading text, or the listening which is situated by the target language.

The relationship between culture and language is as the following: language is a key component of culture. It is the primary medium for transmitting much of culture. Without language, culture would not be possible. Students learning their native language are learning their own culture; learning a second language also involves learning a second culture to varying degrees. On the other hand, language is influenced and shaped by culture. It reflects culture. Cultural differences are the most serious areas causing misunderstanding, unpleasantness and even conflict in cross-cultural communication.

\section{The Intercultural in Language Learning}

Intercultural language teaching and learning centres on the relationship between languagesand culture - it is this relationship that is the starting point for the intercultural. It is possible todistinguish in language education two broad orientations to the teaching of culture that reflect viewsof the nature of the relationship between language and culture.

The first of these can be termed acultural orientation. A cultural orientation implies the development of knowledge about culturethat remains external to the learner and is not intended to confront or transform the learner'sexisting identity, practices, values, attitudes, beliefs and worldview. It is about the acquisition ofa body of knowledge about a culture (Kawakami, 2001; Liddicoat, 2005).

Kawakami (2005) also argues that a focus on teaching the culture of the other as knowledge of differences risks entrenching stereotypical views of the other. This approach to culture, whichis not strongly tied to language and culture is seen as existing independently of language and maybe taught in isolation from the target language itself (Crozet \& Liddicoat, 2000).

The second is anintercultural orientation. This orientation implies a transformational engagement of the learner inthe act of learning. Here learning involves the student in oppositional practice (Kramsch \& Nolden,1994) that seeks to decentre learners from their existing linguistic and cultural positionings andto develop an intercultural identity as a result of an engagement with another culture. Here theborders between self and other are explored, problematised and redrawn. Language is fundamentalto this view of culture as language provides the point of engagement with a culture and it is thoroughengagement with the language and culture as inter-related meaning-making systems that the desiredlearning is achieved. In teaching language from an intercultural perspective developing a static bodyof knowledge is not seen as the equivalent of developing an intercultural capability (Zarate, 1983 in Liddicoat, 2011: 837).Rather, the learner needs to engage with language and culture and elements of a meaning- 
makingsystem that influence and are influenced by each other. This means that language learning becomesa process of exploring the ways language and culture relate to lived realities - the learners' as well asthat of the target community.

Culture, then, is not about information and things; it isabout actions and understanding. In order to learn culture, it is necessary to engage with thelinguistic and non-linguistic practices of the culture and to gain insights about the way of living ina particular cultural context (Kramsch, 1993; Liddicoat, 1997). Cultural knowledge is not a case ofknowing information about the culture; it is about knowing how to engage with diverse others.

The intercultural, therefore, involves an awareness of the interrelationship between languageand culture in the communication and interpretation of meanings. One's understanding is alwaysinformed by the past and present of a particular language and culture and, in intercultural contacts, it is necessary to recognise the same in others (Liddicoat \& Scarino, 2010). This means understandingthe impact of such situatedness on communication and relationships.

For the intercultural language learner, the development of awareness and knowing language and culture is achieved through the experience of another language and through thislanguage of another culture. It is through exposure to and engagement with culturally situated text-whether spoken or written, intrapersonal or interpersonal-that the learner comes to appreciate themanifestation of diversity through language as a communicative process.

Themost elaborated model of intercultural competence is the model of savoirs developed by Byram andZarate (1994): (1) savoir, (2) savoir être, (3) savoir comprendre and (4) savoir apprendre.

(1) Savoir refers to knowledge ofself and others, of their products and practices and the general processes of interaction. This constitutesa body of knowledge in on which other operations can be performed.

(2) savoir être, which involves an attitudinal disposition towards intercultural engagementmanifested in approaching intercultural learning with curiosity, openness and reflexivity.

(3) Savoircomprendre, which involves learning how to interpret and explain cultural practices or documentsand to compare them with aspects of one's own culture;

(4) Savoir apprendre, which is the ability tomake discoveries through personal involvement in social interaction.

(5) Byram (1997) adds a furtherdimension, savoir s'engager, which refers to the ability to make informed critical evaluations of aspectsof one's own and other cultures.

Sercu (2004: 76) has proposed that Byram's model of savoirs beextended to include "a meta-cognitive dimension"; that is, self-regulating mechanisms that enablelearners to plan, monitor and evaluate their own learning processes. In addition to the limitationnoted by Sercu, the model of savoirs does not elaborate on the important ways in which languageaffects culture and culture affects language and how this is understood by the learner. 
Liddicoat et al. (2003) propose a set of principles that provides a starting point for developingintercultural language teaching and learning. These principles are not strictly principles of theintercultural, but rather constitute principles of teaching and learning on which an interculturalpedagogy exists:

1. Active construction: Learning is understood as involving purposeful, active engagement ininterpreting and creating meaning in interaction with others, and continuously reflecting onone's self and others in communication and meaning-making in variable contexts.

2. Making connections: Connections are made between existing conceptions and newunderstandings and between previous experiences and new experiences. Previous knowledgeis challenged and this creates new insights through which students connect, re-organise,elaborate and extend their understanding.

3. Interaction: Learning and communication are social and interactive; interacting andcommunicating interculturally means continuously developing one's own understanding ofthe relationship between one's own framework of language and culture and that of others.

4. Reflection: Learning involves becoming aware of how individuals think, know and learn aboutlanguage, culture, knowing, understanding and the relationship between these, as well asconcepts such as diversity, identity, experiences and one's own intercultural thoughts andfeelings.

5. Responsibility: Learning depends on learner's attitudes, dispositions and values, developedover time.

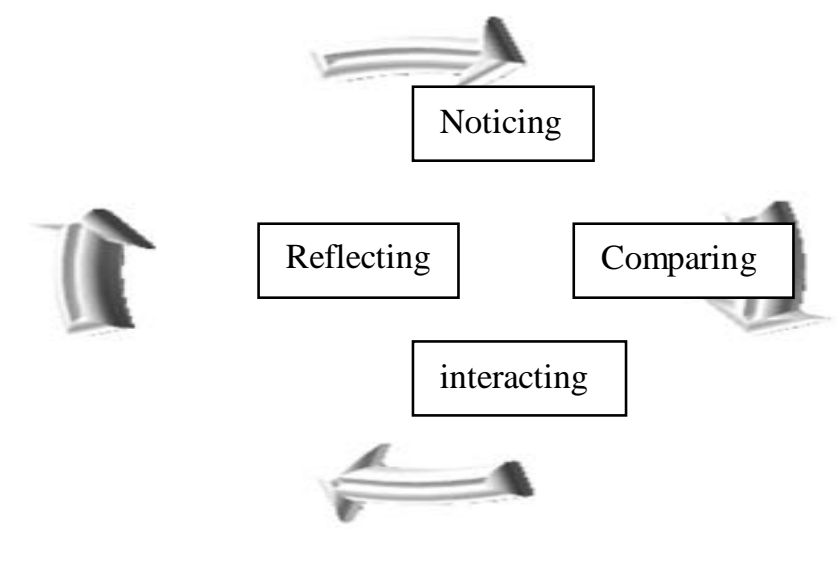

Figure 1. Interacting Processes of Intercultural Pedagogy

Source: Scarino and Liddicoat (2009)

1. involving students in a process of noticing, comparing, reflecting and interacting;

2. constructing the background culture of the learner and the target culture as equally validrepresentations of human life; 
3. viewing instances of language use as experiences of culture and opportunities for culture learning;

4. focusing on the capabilities required for on-going learning about cultures through experiencesof language; and

5. encouraging the inclusion of multiple perspectives.

Through the investigation of culturally contexted meaning, the language learner comes to seelanguage as culturally shaped and as culturally shaping rather than an unproblematised process ofcommunication. In this way, texts open possibilities of new and hitherto undiscovered meanings thatbecome possible for investigation (Kramsch, 2003 in Liddicoat, 2011: 843).

\section{Intercultural Aspects}

Some aspects of intercultural are discussed based on the importance of those aspects in understanding culture. In language we usually find many different things, there are some aspects in language related to culture. Based on Tannen (1990) they can be divided into pattern and structure.

\section{a. Language Patterns}

1) High involvement conversation patterns which tends to talk more, interrupt more, expect to be interrupted, talk more loudly at times and talk more quickly than the second pattern of conversation.

2) High considerateness conversation pattern. The people from the second pattern tend to speak one at a time, use polite listening sounds, refrain from interrupting and give plenty of positive and respectful responses to their conversation partner.

High involvement conversation patterns belong to Russian, Italian, Greek, Spanish, South American, Arab and African. If one person hold the conversation too long and monopolize the conversation, high involvement happened in the conversation.

In general, the various communication style in Asian cultures would be characterized as 'high considerateness', for example Japan and China. The mainstream culture of America also uses that style. Most of Latin America use high considerateness conversation pattern just like Asia.

Indonesia of course uses that pattern because Indonesians always use very polite attitude in speaking: they always wait others speak and never speak before the partner stop speaking. It is a part of Indonesian culture to become very polite and appreciate much someone who is speaking.

\section{b. Conversation Structure}

Beside the two conversation styles, there are two conversation structures, they are:

1) ping-pong and

2) bowling. 
When we observed Americans hold a conversation, it seems that they are having ping-pong game. One person has the ball and then hits it to the other side of the table. The other player hits the ball back and the game continues. If one person doesn't return the ball, then the conversation stops.

The example of ping-pong conversation structure.

Sammy : It's nice to meet you. My friend told me about you. Have you lived in Indonesia long?

John : No, only three months. How about you?

Sammy : I moved here three years ago from California.

John : Oh really! I'm from California too. Where did you live in California?

Sammy : In Gilroy not far from San Jose.

John : This is really a coincidence. I'm from Gilroy, too! I like telling people I'm from the garlic capital of the world. Did you usually go to the summer garlic festival?

Sammy : I used to go every summer. How about you?

John : I went to most of them. I thought the one in 1980 was great. Did you go to that one?

Seeing the conversation it can be concluded that the conversation is interactive because the speaker always respond the questions then give the question again. The conversation is like ping-pong game.

Another conversation structure is bowling game. We can see the conversation is not interactive because the second speaker is just answering the questions from the first speaker. Here is the example:

John : Where are you from?

Alan : Hello.

Dea : From New York.

Alan : Why did you come to California?

Dea : To study

Alan : Oh, what are you studying?

Dea : Physics

Alan : How long do you plan to stay here?

Dea : Two years.

Alan : When did you come?

Dea : Three weeks ago

This is one-sided conversation. Dea never gives comment or ask Alan but she always answers the questions shortly. Alan is already feeling frustrated, he thinks it is not worth getting to know Dea. This conversation is like playing bowling.

Most Americans do the ping-pong style. Athough they appreciate much someone's speaking but they respond quickly someone's speaking and eyecontact is very important for them. 
For Indonesians they like to have bowling style because they are very polite so they wait for the questions, let alone when they speak to strangers. In Java the people are very careful in answering someone's question so they also use bowling style.

The pattern and the structure of conversation will depend on their culture. If the culture demands them to be very polite then they will be included in high considerateness and bowling styles. The culture creates them to be someone who appreciate others much.

If the daily routine demands them to be very quickly and fast in doing everything they will be included in high involvement and ping-pong style.

\section{Nonverbal Language: Gestures}

Gestures are specific body movements that carry meaning. Hand motions alone can convey many meanings: "Come here," "Go away,". "It's O.K," and "That's expensive!" are other examples.

Beckoning people to come with the palm up is common in United States but in Philipinnes, Korea and parts of Latin America as well as other countries is considered rude because it's only animal that would be beckoned with the palm up.

Many American business executives enjoy relaxing with their feet up on their desks, but to show person from Saudi Arabia or Thailand the sole of one's foot is extremely insulting because foot is considered the dirtiest part of the body.

Our faces reveal emotions and attitudes but we should not read someone faces based on our culture because it will have different perception. Americans show their emotion directly and freely differs from Japan do.

\section{Directness and Indirectness}

There are several expressions in English that emphasize the importance of being direct:

"Get to the point!

Don't beat around the bush!

Let's get down to business!" .

These sayings all indicate the importance of dealing directly with issues rather than avoiding them. One way to determine whether a culture favors a direct or indirect style in communication is to find out how the people in that culture express disagreement or how they say, "No."

In Japan, there are at least fifteen ways of saying ,"No", without actually saying the word. Similarly in Japan, it would be considered to say directly, "I disagree with you," or "You're wrong". In this case it is the same as Indonesia: Indonesian will say "No" for the first time you offer them food or something but if it is repeated two or three times they will say "OK".

Many Americans believe that 'honesty is the best policy' and their communication style reflect this. Honesty and directness in communication are strongly related. It is not surprising to find out that cultural groups misjudge each other based on different beliefs about directness and honesty in communication.

3. Concept of Time 


\section{a. Polychronicity}

Polychronicity is the extent to which people (1) prefer to be engaged in two or more tasks or events simultaneously and are actually so engaged ..., and (2) believe their preference is the best way to do things (Bluedorn, 2002: 51).

Polychronic individuals, on the other hand, are more flexible about time schedules; they have no problem integrating task-oriented activities with socioemotional ones. For them, maintaining relationships and socializing are more important than accomplishing tasks. These individuals usually see time in a more holistic manner; in other words, many events may happen at once. Latin America, the Middle East, and Africa are places where the polychronic orientation prevails.

In certain cities in the U.S., it is not uncommon for us to find timetables or daily schedules for buses or trains. If the bus is to be at a certain stop at 10:09 PM, for example, one can expect that to happen at the designated time, give or take a minute.

For polychronic individuals such precise timetables are mind-boggling, as many of them are simply used to going to the bus stop and waiting - not knowing whether they will be waiting for five or forty-five minutes. That is just the way things are.

This difference in time orientation is reflected in the complaints of U.S. business people conducting business in Saudi Arabia or in Mexico, for example. A big source of frustration for them is the difficulty of getting through a meeting's agenda. That is because in these countries meetings begin with an extended socializing time in which time is spent establishing social rapport - usually over many cups of coffee or tea.

In the work to date on polychronicity, the key question has been, "How many things do you like to do at once?" (Bluedorn, Kaufman, \& Lane, 1992). Bluedorn (2002: 49) stated that "polychronicity is about how many activities and events people engage at once". An example is driving and eating at the same time, or when two projects are being worked on within the same time frame. It can also involve relationships, such as when one talks on the phone and watches television simultaneously.

\section{b. Monochronicity}

Monochronic time system means that things are done one at a time and time is segmented into precise, small unit. Under this system time is scheduled, arranged and managed. For American times is presicious resource not to be wasted, not taken lightly. We buy time, save time, spend time and make time. Our time to structure both our daily lives and events that we are playing for the future. We have schedules that we must follow: Appointments that we must go to at a certain time, classes that start and end at a certain time.

Monochronic individuals are those who prefer to complete one task at a time. For them, task-oriented time is distinguished from socio-emotional time. In other words, there is a time to play and a time to work. These individuals value punctuality, completing tasks, and keeping to schedules. They view time as if it were linear, that is, one event happening at a time. 
For monochronic cultures, such as the American culture, "time is tangible" and viewed as a commodity where "time is money" or "time is wasted." The result of this perspective is that Americans and other monochronic cultures, such as the German and Swiss, place a paramount value on schedules, tasks and "getting the job done." These cultures are committed to regimented schedules and may view those who do not subscribe to the same perception of time as disrespectful. Monochronic cultures include Germany, Canada, Switzerland, United States, and Scandinavia, Israel. http://www.celt.iastate.edu/international/CulturalDifferences3.html

4. Individualism vs Collectivism

Individualism versus collectivism is not the sole measure of cultural differences, but it has been highly significant in the delineation of individual and group behavior, goal achievement, and relationship importance (Earley \& Gibson, 1998; Triandis, 2002a, 2002b). The dimension of individualism versus collectivism has been found to account for a significant amount of variance in the social behavior of individuals across cultures (Triandis, 1995).

People generally do not fit at the extremes of behavior, as defined in the concept of individualism or collectivism; "people are always gray - never black or white" (Singelis, et.al., 1995: 243). Individualism, taken to its extreme, is selfishness; extreme collectivism is tyranny (Hofstede 1991).

In brief, individualists tend to prefer working alone, with personal goals of primary importance, while collectivists tend to prefer working in groups, with group goals of primary importance. Indonesians are collectivist with the symbol of togetherness in "Bhineka Tunggal Ika" and the principle of gotong royong and musyawarah.

\section{CONCLUSION}

Language is a major component and supporter of culture as well as a primary tool for transferring message, which is inextricably bound with culture. Learning a second language also involves learning a second culture to varying degrees. On the other hand, language is influenced and shaped by culture. It reflects culture. Cultural differences are the most serious areas causing misunderstanding, unpleasantness and even conflict in cross-cultural communication. Therefore, both foreign language learners and teachers should pay more attention to cultural communication information.

\section{REFERENCES}

Appiah, A. (2006). Cosmopolitanism: ethics in a world of strangers, 1st edn, W.W. Norton, New York.

Arigatou Foundation.(2008). Learning to Live Together: an intercultural and interfaith programme for ethics education, Arigatou Foundation, Geneva, Switzerland. 
Banks, J.A. \& Banks, C.A.M. (eds) (2004). Multicultural Education: issues and perspectives, 5th edn, John Wiley \& Sons, Hoboken, NJ.

Bluedorn, A.C. (2002). The Human Organization of Time: Temporal Realities and Experience. Stanford, CA: Stanford University Press.

Brisbane Catholic Education.(1999). Cultural literacy across the curriculum. A framework. pp.7\&ndash;8. Brisbane: Author.

Byram, M. (2008). From Foreign Language Education to Education for Intercultural Citizenship: essays and reflections, Multilingual Matters Ltd, Clevedon, Buffalo, England; Multilingual Matters, Buffalo, NY.

Earley, P. C. \& Gibson, C. B. (1998). Taking stock in our progress on individualism-collectivism: 100 years of solidarity and community. Journal of Management, 24: 265-304.

Hall, S. (ed) (1997). Representation: cultural representations and signifying practices, Sage, in association with The Open University, London.

http://www.celt.iastate.edu/international/CulturalDifferences3.html

http://www.australiancurriculum.edu.au/english/general-capabilities

http://www.asiaeducation.edu.au/for_teachers/professional_learning/intercultural_ competencies/developing_intercultural_understanding/diu_resources/resourc e_1_definitions.html

http://www1.gdufs.edu.cn/jwc/bestcourse/kecheng/38/whjiaoan/files/intro.html

Hofstede, G. 2001. Culture's Consequences: International Differences in Work-related Values ( $2^{\text {nd }}$ ed). Beverly Hills, CA: Sage.

Janke, T. (2008). 'Indigenous knowledge and intellectual property: negotiating the spaces', The Australian Journal of Indigenous Education, vol. 37, pp. 14-24.

Kalantzis, M. \& Cope, B. (2005). Learning by Design, Common Ground Publishing, Melbourne.

Knapp, Karlfried and Seidlhofer, Barbara. (2009). Handbook of Foreign Language Communication and Learning, . Berlin: Walter de Gruyter GmbH \& Co. KG, D-10785

Kramsch, C.J. (1998). Language and Culture, Oxford University Press, Oxford.

Liddicoat, A., Lo Bianco, J. \& Crozet, C. (eds) (1999)., Striving for the Third Place: intercultural competence through language education, Language Australia, Canberra. 
Liddicoat, A., Papademetre, L., Scarino, A. \& Kohler, M. (2003). Report on Intercultural Language Learning, Commonwealth of Australia, ACT.

Liddicoat, Anthony J. 2011. Language Teaching and Learning from an Intercultural Perspective. London: Routledge in Eli Hinkel. 2011. Handbook of Research in Second Language Teaching and Learning Volume II. New York: Routledge

Nakata, M. (2007). 'The cultural interface', The Australian Journal of Indigenous Education, vol. 36, pp. 7-14.

Noble, G. \& Poynting, S. (2000). 'Multicultural Education and Intercultural Understanding: Ethnicity, Culture and Schooling', in C. Scott and S. Dinham (eds), Teaching in Context, pp. 56-81, Australian Council for Educational Research, Camberwell, Victoria.

Scarino, A., Dellitt, J. \& Vale, D. (2007). A Rationale for Language Learning in the 21st Century:www.mltasa.asn.au/rationale.htm (accessed 13March 2014).

Singelis, T.M., Triandis, H.C., Bhawuk, D.P.S., \& Gelfand, M. 1995. Horizontal and vertical dimensions of individualism and collectivism: A theoretical and measurement refinement. Cross-Cultural Research, 29: 240-275.

Sleeter, C. \& Grant, C. (2003). Making Choices for Multicultural Education: five approaches to race, class, and gender, John Wiley \& Sons, New York.

Tannen, Deborah (1990) You Just Don't Understand: Women and Men in Conversation. New York: Morrow.

Triandis, H.C. 2002a. Motivation to work in cross-cultural perspective. In J.M. Brett \& F. Drasgow (eds.) The Psychology of Work: Theoretically Based Empirical Research(pp. 101-118). Mahwah, NJ: Lawrence Erlbaum Associates Publishers.

Triandis, H.C. 2002b. Generic individualism and collectivism. In M.J. Gannon \& K.L. Newman (eds.), The Blackwell Handbook of Cross-Cultural Management (pp.16-45). Oxford, U.K.: Blackwell Business.

United Nations Educational, Scientific and Cultural Organization (2006). Guidelines on Intercultural Education, Paris: http://unesdoc.unesco.org (accessed 15 March 2014)

Wiggins, G.P. \& McTighe, J. (2005). Understanding by Design, expanded 2nd edn, Pearson/Merrill Prentice Hall, New Jersey. 